- Short communication

\title{
A preliminary study on the Orchids of National Botanical Garden, Mirpur, Dhaka, Bangladesh
}

\author{
M. Mahfuzur Rahman* and Tahmina Akhtar \\ Plant Ecology and Environment Laboratory, Department of Botany, \\ Jahangirnagar University, Savar, Dhaka-1342, Bangladesh
}

Key words: Orchid diversity, National Botanical Garden, Bangladesh.

The Orchids, comprising a unique group of plants, are one of the most diverse and beautiful of all flowers with colorful and fragrant or non-fragrant flowers belonging to the family Orchidaceae. Orchidaceae is one of the largest families of flowering plants and so far about 25000-35000 species under 600-800 genera have been recorded in this family (Garay, 1960). Orchids with their various ranges of flowers and beautiful colour combinations especially, their longevity provides a source of profound aesthetic pleasure to both owners and visitors (Bose \& Yadav, 1989). Most of the orchids are perennial herbs with simple leaves. Large number of Orchids are epiphytes or terrestrial and some are saprophytes and leafless in nature (Larson, 1980). Majority of the cultivated orchids are native of tropical countries and occur in their greatest diversity in humid tropical forests of South and Central America, Mexico, India, Burma, South China, Thailand, Malaysia, Australia. A total of 179 Orchid species under 70 genera have been reported to grow in Bangladesh (Ahmed et al., 2008), of which mostly are epiphytic and some are ground orchids. Different species of Vanda, Dendrobium and Cymbidium are commonly found in the natural habitats of hilly areas of Chittagong Hill Tracts, Mymensingh and Sylhet. Though, till now orchids have been grown naturally and in some case as home garden but in recent years, the commercial production and demand of orchids in Bangladesh have been increased quite rapidly. Some NGO including BRAC, PROSHIKA and private nursery namely, Kingsuk, Dipta Orchids, Micro Orchids and Plants, OMNI Orchids are producing orchids commercially for local market.

Present research work was aimed to know the orchid diversity of Bangladesh National Botanical Garden through proper documentation of different orchid plants grown in the orchid houses of the garden. Field studies were carried out from February to July, 2012. By this time, six visits were made at Bangladesh National Botanical Garden. A wide level of morphological variation was observed among all the species. Various characters in case of flowering were observed. Variation on the longevity of orchid flower was the most important observation. Collected plant materials were matched with the available voucher specimens in Bangladesh National Herbarium (DACB) to identify the specimens.

\footnotetext{
* Corresponding author: Email: mmrahman1518@gmail.com
} 
Different relevant literatures (Ahmed et al., 2008; Hossain et al., 2009; Huda, 2008; Islam, 2003; King \& Pantling, 1898; Misra, 2007; Pasha \& Uddin. 2013; Wood, 2006) on orchids available in the Department of Botany and Central library of Jahangirnagar University, Bangladesh National Botanical Garden library and Bangladesh National Herbarium library were consulted. Morphological data, specially flower colour and longevity of each orchid species were studied and recorded. Consulting to the Bangladesh National Botanical Garden authority and to the caretakers of the Orchid house the valuable information were gathered and recorded. The cultivation and caring procedures of the plants were observed at different times. During the investigation a total of 31 orchid species have been recorded and identified which were categorized into Natural and Hybridized Orchids (Table 1.A and Table 1.B).

Table 1.A. Recorded natural orchid diversity in National Botanical Garden, Mirpur, Dhaka

\begin{tabular}{|c|c|c|c|c|c|}
\hline $\begin{array}{l}\text { Sl. } \\
\text { no. }\end{array}$ & Scientific name & $\begin{array}{l}\text { Bengali } \\
\text { name }\end{array}$ & English name & Flower color & $\begin{array}{l}\text { Flower } \\
\text { longevity } \\
\text { (days) }\end{array}$ \\
\hline 1 & Aerides odorata Lour. & Shukphul & & White with purple shade & $40-50$ \\
\hline 2 & $\begin{array}{l}\text { Arundina graminifolia } \\
\text { (D.Don.) Hochr. } \\
\text { (Ground orchid) }\end{array}$ & Ghasphul & Bird orchid & $\begin{array}{l}\text { Deep to light purple } \\
\text { with whitish margin }\end{array}$ & $15-20$ \\
\hline 3 & $\begin{array}{l}\text { Cattleya mossiae } \\
\text { C.Parker ex Hook. }\end{array}$ & & $\begin{array}{l}\text { Easter } \\
\text { Cattleya }\end{array}$ & Deep pink & $30-35$ \\
\hline 4 & Cattleya sp. & & & Red & $30-35$ \\
\hline 5 & $\begin{array}{l}\text { Cymbidium aloifolium } \\
\text { (L.) Sw. }\end{array}$ & $\begin{array}{l}\text { Churi, } \\
\text { Tosabak }\end{array}$ & & Yellow and dark purple & $30-40$ \\
\hline 6 & Dendrobium adastra & & & Dark pink, whitish & $25-30$ \\
\hline 7 & $\begin{array}{l}\text { Dendrobium aphyllum } \\
\text { (Roxb.) C.E.C. Fisch. }\end{array}$ & & $\begin{array}{l}\text { Primose } \\
\text { yellow }\end{array}$ & White, slightly pinkish & $25-30$ \\
\hline 8 & Dendrobium kingianum & & Pink rock orchid & Deep magenta & $30-35$ \\
\hline 9 & Dendrobium nobile Lindl. & & & White with dark pink & $30-35$ \\
\hline 10 & $\begin{array}{l}\text { Dendrobium palpebrae } \\
\text { Lindl. }\end{array}$ & Nobirian & & Deep yellow & $15-20$ \\
\hline 11 & Dendrobium sp. & & & White, slightly greenish & $30-35$ \\
\hline 12 & $\begin{array}{l}\text { Eria tomentosa (J.König) } \\
\text { Hook.f. }\end{array}$ & Woolen-iria & & Brown & $35-45$ \\
\hline 13 & Oncidium amabile & & & White & $30-40$ \\
\hline 14 & $\begin{array}{l}\text { Papilionanthe teres } \\
\text { (Roxb.) Schltr. }\end{array}$ & Paphoteri & & $\begin{array}{l}\text { Darker pink with yellow } \\
\text { base veined with pink }\end{array}$ & $30-40$ \\
\hline 15 & $\begin{array}{l}\text { Phaius tankervillii } \\
\text { (Banks) Blume } \\
\text { (Ground orchid) }\end{array}$ & Tankaphai & Nun's orchid & $\begin{array}{l}\text { Bronze-white to } \\
\text { purplish }\end{array}$ & $40-50$ \\
\hline 16 & Pholidota pallid & & & White brownish & $30-35$ \\
\hline 17 & $\begin{array}{l}\text { Rhynchostylis retusa (L.) } \\
\text { Blume }\end{array}$ & Shial leja & $\begin{array}{l}\text { Fox Tail } \\
\text { Orchid }\end{array}$ & Pink purple to whitish & $45-50$ \\
\hline 18 & $\begin{array}{l}\text { Spathoglottis plicata } \\
\text { Blume. } \\
\text { (Ground orchid) }\end{array}$ & Kantaglottis & $\begin{array}{l}\text { Large Purple } \\
\text { orchid }\end{array}$ & Dark pink & $20-25$ \\
\hline 19 & Vanda $s p$ & & & Yellow & $30-35$ \\
\hline 20 & $\begin{array}{l}\text { Vanda tassellata (Roxb.) } \\
\text { Hook.f.ex G.Don }\end{array}$ & Rasna & & $\begin{array}{l}\text { Brown, violet and } \\
\text { whitish }\end{array}$ & $40-45$ \\
\hline
\end{tabular}


Table 1.B. Recorded hybrid orchid diversity in National Botanical Garden, Mirpur, Dhaka

\begin{tabular}{c|l|l|c}
\hline $\begin{array}{c}\text { Sl. } \\
\text { no. }\end{array}$ & Trade Name & Flower color & $\begin{array}{c}\text { Flower longevity } \\
\text { (days) }\end{array}$ \\
\hline 1 & Ascocenda Princess Mikasa Pink & Brightly purple colored \\
& & $\begin{array}{l}\text { overlaid with contrasting color } \\
\text { Deep orange }\end{array}$ & $50-60$ \\
2 & Aranda Hybrid & Deep red & $35-40$ \\
3 & Cattleya Sun Yun Ruby & Brown and deep yellow & $20-25$ \\
4 & Dendrobium Bonckoo Gold & White, yellowish and deep & $30-35$ \\
5 & Dendrobium Charming White & magenta within & $30-35$ \\
& & Deep magenta with red & $30-40$ \\
6 & Dendrobium Golden Magenta & Dark orange yellow & $40-45$ \\
7 & Dendrobium King Kobra & Very dark magenta & $40-45$ \\
8 & Dendrobium Sonia Red & Yellow with spotted & $35-40$ \\
9 & Mokara Golden Tommy & Brown, yellow & $50-55$ \\
10 & Mokara Leunberger Gold & Not recorded yet & Not recorded yet \\
11 & Papilionanthe teres hybrid & &
\end{tabular}

Of these, the epiphytic orchids have been found to be advanced in their flowering. They possess more showy and attractive flowers with more longevity than the others. They need more care and nutrition for growth and flowering. The overall performance of Aerides odorata Lour., Cymbidium aloifolium (L.) Sw., Eria tomentosa (J.König) Hook.f., Rhynchostylis retusa (L.) Blume and Vanda tassellata (Roxb.) Hook.f.ex G.Don is better specially, in respect to flower colour and their durability. They also possess very good medicinal values and ethnobotanical importance (Pal \& Jain, 1998; Rao \& Henry, 1995). Among all the recored orchids, the hybrid Ascocenda Princess Mikasa Pink showed the highest flower longevity up to average of 55 days. The orchid plants that are propagated by tissue culture method are more vigorous in growth and flowering such as, Cymbidium aloifolium. As Mirpur Botanical Garden is our National Garden, so authentication of botanical enumeration of orchids grown there has been very important which was achieved through the present piece of research.

\section{REFERENCES}

Ahmed Z.U., Hassan M.A., Begum, Z.N.T. Khondokar, M. Kobir, S.M.H. Ahmad, M. Ahmed, A.T.A. Rahman, A. K.A. Haque, E.U. (eds). 2008. Encyclopedia of Flora and Fauna of Bangladesh, Vol. 12. Angiosperms: Monocotyledons (Orchidaceae-Zingiberaceae). Asiatic Society of Bangladesh. Dhaka.

Bose. T.K. and L.P. Yadav. 1989. Orchids. In "Commercial Flowers", $1^{\text {st }}$ Ed. B. Mitra, Naya Prakash. Calcutta, India. pp. 151-247.

Garay, L. 1960. On the origin of orchidaceae. Proc. $3^{\text {rd }}$. World Orchid Conference, pp172-195.

Hossain, A.B.M.E.M., Didarul Alam, M. A. Rahim, Md. Abdur Rahim. 2009. A pictorial Guide to Nursery Plants.

Huda, M.K. 2008. Encyclopedia of Flora and Fauna of Bangladesh, Vol. 12. Angiosperms: Monocotyledons (Orchidaceae). Asiatic Society of Bangladesh. Dhaka. pp. 1-149.

Islam, S. (Ed.). 2003. BANGLAPEDIA. Vol. 7. Asiatic Society of Bangladesh. Asiatic Society of Bangladesh. Dhaka. 
King, G. and R. Pantling. 1898. The orchids of Sikkim Himalaya. Ann. Roy. Bot. Gard. (Calcutta) 8: $1-212$.

Larson, R.A. 1980. Introduction to Floriculture. Acad. Press, USA.

Misra, S. 2007. Orchids of India, a glimpse. Bishen Singh Mahendra Pal Singh. Dehradun, India.

Pal, D.C. and Jain, S.K. 1998. Tribal Medicin. Naya Prokash, Calcutta, India. pp. 1-317.

Pasha, M.K. and Uddin, S. B. 2013. Dictionary of Plant Names of Bangladesh.

Rao, N. R. and Henry, A.N. 1995. The Ethnobotany of Eastern Ghats in Andra Pradesh, India. Botanical Survey of India, Govt. Press of India. pp. 259.

Wood, H. P. 2006. The Dendrobiums. A. R. G. Gantner Verlag K. G., Germany. 